\title{
Risk Analysis in Halal Fast Food Supply Chain Restaurant using Risk Map Method
}

\begin{abstract}
Putri Amalia
Industrial Engineering Department, Universitas Islam Indonesia Kaliurang, Yogyakarta, Indonesia 17522035@students.uii.ac.id

Nurfitria Handayani Industrial Engineering Department, Universitas Islam Indonesia Kaliurang, Yogyakarta, Indonesia

Maeva Apriza
Industrial Engineering Department,
Universitas Islam Indonesia
Kaliurang, Yogyakarta, Indonesia
Elisa Kusrini
Industrial Engineering Department,
Universitas Islam Indonesia
Kaliurang, Yogyakarta, Indonesia
\end{abstract}

\begin{abstract}
Halal food has increasing demand in recent years. Many countries are promoting its tourism and culinary by providing halal status. In order to implement Halal system which is used to obtain Halal status, the culinary or restaurant company should accomplish several requirements that covers from many stakeholders in their supply chain management such as supplier, logistics, and production process. Hence, there are some risks obtained in conducting Halal supply chain system. The risks found at this research are from its business process which is procurement, raw material delivery, inventory, production, and consumer. From those processes, the risks discovered are listed and assigned with their severity and probability, ended up in Risk Priority Index. The risks then ranked and mapped in the risk map in order to know which risks that has high impacts. Some responses are proposed to overcome the critical risks, such as sanitary checking before delivered to the customer, make some chambers, and make SOP related to hygiene of the kitchen.
\end{abstract}

Keywords: Halal Supply Chain, Risk Assessment, Halal Restaurant

\section{INTRODUCTION}

Almost all people in the world ever eat in a fast food restaurant, since the consumption of fast food is increasing in the past years [1]. The main consumer of it is the young generations [2]. A restaurant company will do anything to make their products well-sold, because the main business process in restaurant is purchasing and selling [3].

In order to increase the sales, the restaurant should be able to follow the today's trend and recently, halal tourism is very popular [4]. As the tourism sector escalates, the order for halal products and services also raises [5]. As halal is a characteristics and law that Muslim people should obey [6], many non-Muslim countries are starting to develop halal tourism and services as a strategy to increase their revenue [7,8]. With the advancement of it, the economic value will be increased because the world is more to be religion-inclusive [6]. One of the halal tourism aspects is culinary, which is an important and promising market because food is the basic need among people [9]. Halal food is not only for Muslim, but it can be bought by non-Muslim since it is known healthier than other food [8]. As one of the top 10 in global Islamic economy [10], Indonesia should implement the halal food in a strict and in line with Syariah law.

Halal status is very important and complex, because it influences people to buy the products offered [11]. Hence, it also generates many risks in order to do it [12] as in conducting the business, supply chain is critical and the relationship between their supplier and business partner are important [13,14]. Risks are generated from the supply chain, so the people that in charge in the processes should be aware of those risks [15]. In order to reduce the risk that may be occurred, risk assessment may be used as it is able to increase the effectiveness in the decision making to conduct and implement risk reduction actions [16]. Risk assessment is a part of risk management, which is the important thing to be completed in a project [17]. This research will be focused on the halal risk assessment and mitigation as a part of risk management in a fast food restaurant company in Indonesia.

A previous research has been worked out by de Araújo [18] about the production process of halal meat and poultry. The case study was in Brazil, non-Muslim majority country that has provided halal status to its meat and poultry products. The research brings the process of how halal system implemented. It is found that the production of halal meat is consists of several stakeholders that should also implement halal system and the practical things in doing the halal meat and poultry business, such as certification, process transformation, 
and mobilization. Halal control points in poultry were clearly explained by Shahdan et al. [19], by identifying the guidelines and the current position of implementation. The researchers then proposed several control points in poultry system from the on farm, transportation and slaughtering process.

Marzuki et al. [20] brought up the research about halal certification in restaurant. It found out the customers of the restaurant by conducting demographic, factor, reliability, and cluster analysis. The result of this research is to prove that in conducting hospitality industry, halal certification leads to the commercial perspectives. Another research in halal tourism industry was conducted by Henderson [21] that focused on the halal food as a tourism market attraction in Malaysia and Singapore. It discovered that halal food attracts more market since many non-Muslim also having high acceptance of halal food.

In term of supply chain management, Hijrah et al. [22] discovered several issues in the customer consideration towards Halal food. The issues are: the role of attention and perception, reliability of supply chain, the consistency and law about the Halal status, and about the uniting of halal food with the non-halal one. The case study of halal risk analysis by Wahyuni et al. [23] was about the slaughterhouse and the methods used are SCOR and HOR. In the slaughterhouse, as in the paper, there are five risk agents that should be taken into account: the cleanliness of workplace, the blood waste management, the machine management, and request management. By several studies that has been carried out, this paper will conduct research about the halal risk management at fast food restaurant using risk map method.

\section{RESEARCH METHODS}

This research carried out risk management process in an Indonesian fast food restaurant company. As in [24], the supply chain of the restaurant is procurement, distribution, inventory or storage, production, and selling or handing to customers. The steps in conducting this research are:

- Analyse the halal control points in every business process.

- List and mark each risk and calculate risk priority index (RPI).

- Draw Risk Heat Map based on the analysed risks and RPI.

- Propose some suggestions to prevent future risks.

$$
R P I=S i x P i
$$

Where:

$\mathrm{Si}=$ Severity Index and $\mathrm{Pi}=$ Probability Index

\section{RESULT AND DISCUSSION}

\subsection{Halal control point of restaurant supply chain}

Identify the halal control point should be related to its supply chain flow from the beginning to the end consumer. There are five activities of restaurant supply chain that should compliance with the halal requirement. Therefore, by determining the halal control point (HCP) it can shows the halal point to meet its requirement. For more detail, in the first activity such as procurement has $3 \mathrm{HCPs}$, while the raw material delivery, inventory, production, and consumer have $1 \mathrm{HCP}$ for each activity. In the procurement activity has more halal critical point and also gets more halal risk activity that will happen. Figure 1 shows the supply chain flow with each halal critical point.

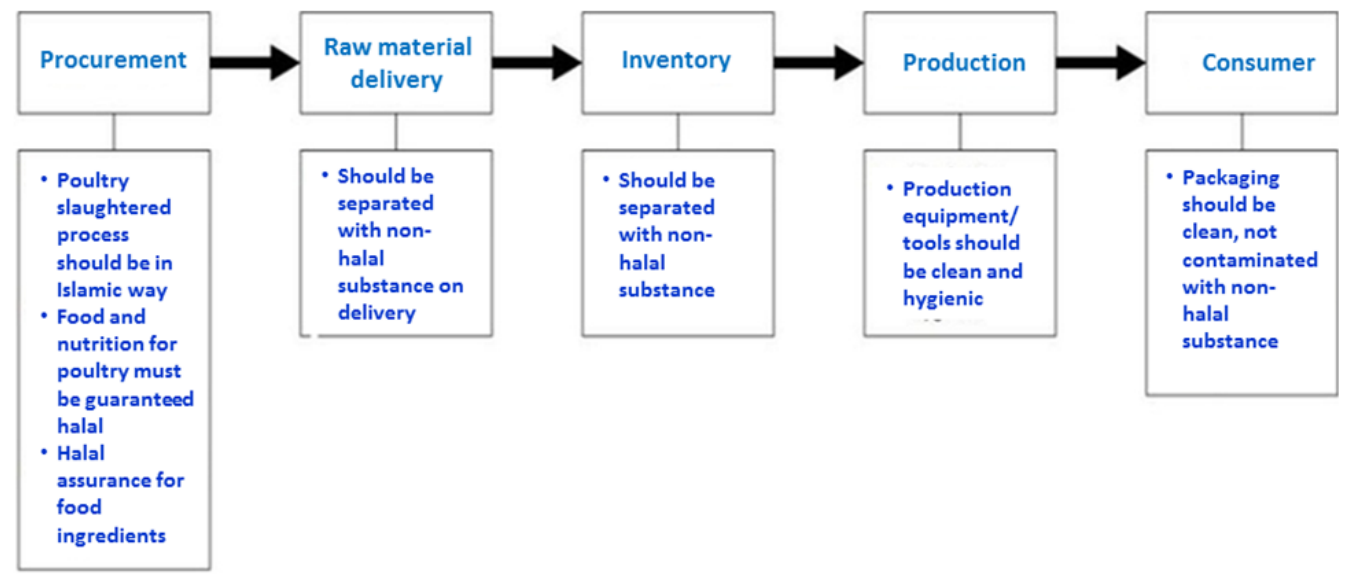

Figure 1: Supply chain flow of fast food restaurant 


\subsection{Supply chain Risk identification}

Risk identification is carried out to determine the risks that occur in the company's activities that can potentially happen and affect the company's supply chain activities (Table 1). The risks are identified based on the business process activity where done by the company. Risk identification should be done by the company in early of the project. Because the sooner the risk is identified, the sooner manager or stakeholder will get the way to solve to mitigate them, so the risk will not exposure to be greater. There are 11 risk events that were identified by the researcher. Following is a table identifying risk events that occurred at fast food restaurant supply chain.

Table 1: Risk event of halal product

\begin{tabular}{l|c}
\hline \multicolumn{1}{c|}{ Risk Event } & Code \\
\hline Procurement & E1 \\
\hline The slaughtering process is not in line with Syariah & E2 \\
\hline Unclear halal status of the raw material & E3 \\
\hline The raw material exceeds the expiration date & E4 \\
\hline Delivery & \\
\hline Unclean containers and transportation & E5 \\
\hline Inventory & E6 \\
\hline Raw material is contaminated by non-halal substance & \\
\hline Power failure that leads to bacterial growth in the raw materials & E7 \\
\hline Production & E8 \\
\hline Deficient manner in cooking & E9 \\
\hline Not thorough in cleaning food ingredients & E10 \\
\hline The cooking utensil is not hygiene & \\
\hline Unclear production environment & E11 \\
\hline Consumer & \\
\hline Packaging contaminated with non-halal substance & \\
\hline
\end{tabular}

\subsection{Priority index determination}

The RPI value is the multiplication result of the probability value and the severity value of each risk event. The level of probability is describing how many times the risk occurs in a month. The level rating starts from 1, which never occurs or maximum only 1-5 times in a month, which always occurs maximum 20 times. The severity level describes the impact of the risk to the halal status of the product with rating level starts from 1 that will not give any impact to the halal status of the product to 5, which the impact will lose the product's halal status. The value of the RPI illustrates how substantial the risk is to the sustainability of the project. Table 2 shows RPI values for each risk event.

Table 2: Risk priority index of halal product

\begin{tabular}{c|c|c|c}
\hline Risk Event & Code & Severity & Probability \\
\hline The slaughtering process is not in line with Syariah & E1 & 3 & 4 \\
\hline Unclear halal status of the raw material & E2 & 2 & 3 \\
\hline The raw material exceeds the expiration date & E3 & 5 & 4 \\
\hline Unclean containers and transportation & E4 & 2 & 2 \\
\hline Raw material is contaminated by non-halal & & & 3 \\
\hline substance & E5 & 5 & \\
\hline Power failure that leads to bacterial growth in the \\
raw materials & & & 2 \\
\hline Deficient manner in cooking & E6 & 1 & 3 \\
\hline Not thorough in cleaning food ingredients & E8 & 2 & 3 \\
\hline Not thorough in cleaning food ingredients & E8 & 2 & 3 \\
\hline
\end{tabular}




\begin{tabular}{c|c|c|c}
\hline The cooking utensil is not hygiene & E9 & 3 & 3 \\
\hline Unclear production environment & E10 & 2 & 3 \\
\hline Packaging contaminated with non-halal substance & E11 & 2 & 2 \\
\hline
\end{tabular}

\subsection{Risk map matrix}

Risk map are made from the risk priority index value between the probability of a risk event and the risk event's impact. This matrix is divided into three risk categories, namely high risk, moderate risk, low risk. The identified risks are categorized into three risk categories in different colours. The orange colour shows that the risk is in the high-risk category, yellow colour shows medium, and the green colour show the low-risk level (Figure 2).

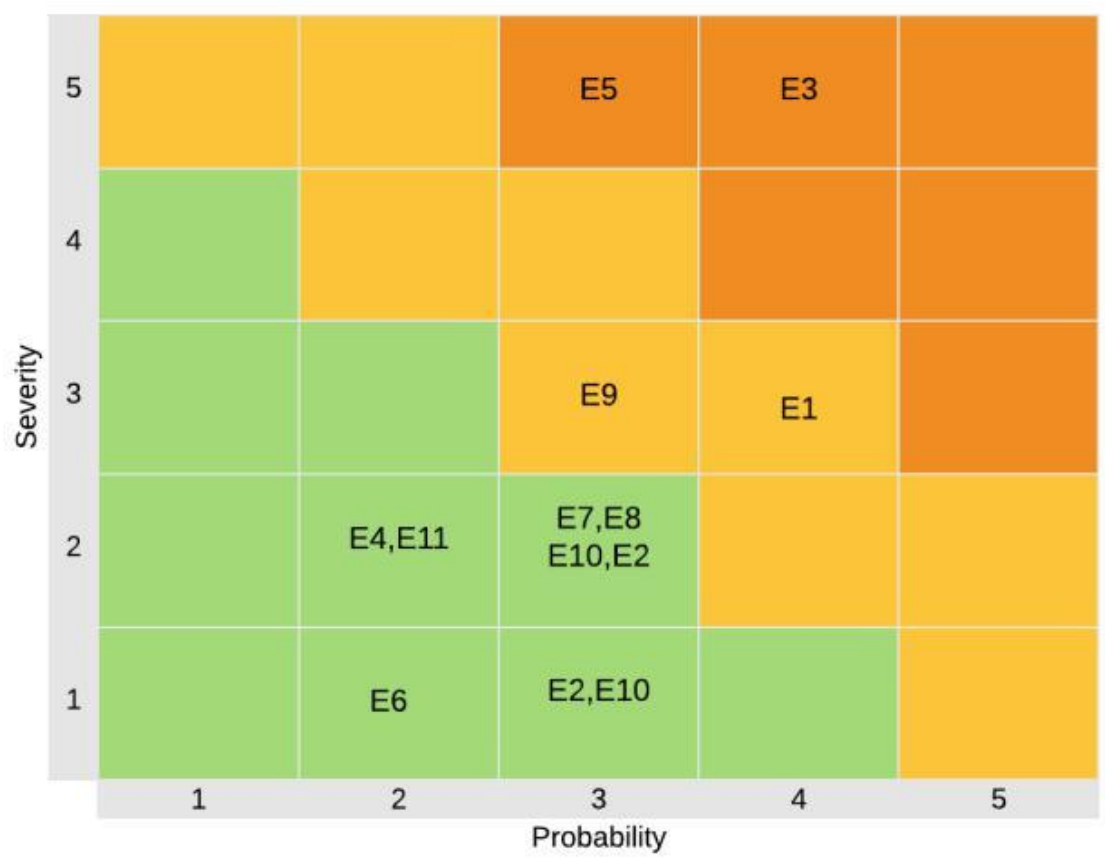

Figure 2: Risk map matrix

Based on the risk map matrix result before, most of the risk is at low levels. Those who categorized in low levels are unclear statements of halal status of the material, unclean transportation of containers, power failure, deficient cooking manner, not thorough cleaning the ingredients, unclean production environment, and packaging that contaminated with the non-halal substance. Risks that fall into the category of low risk have a low probability they will occur, and the impact that appears does not make the product losing its halal status. Therefore, the risk categories to be handled are only risks that are at medium and high levels. Table 3 shows risks that will be controlled and mitigated.

Table 3: Critical risk event of halal product

\begin{tabular}{l|c|c}
\hline \multicolumn{1}{c|}{ Risk Event } & Code & Status \\
\hline The slaughtering process is not in line with Syariah & E1 & Medium \\
\hline The raw material exceeds the expiration date & E3 & High \\
\hline Raw material is contaminated by non-halal substance & E5 & High \\
\hline The cooking utensil is not hygiene & E9 & Medium \\
\hline
\end{tabular}

\subsection{Risk response and mitigation}

Risk mitigation is a way to manage risks and reduce the consequences of risks and prioritize risk management follow-up with the highest total effectiveness and cost-efficient. The most significant risks identified in the procurement process are risk event coded E1, the slaughtering process is not in line with Syariah, the raw 
material exceeds the expiration date by code E3. In addition, in the inventory and production process also has significant risk that had been identified such as raw material is contaminated by non-halal substance and cooking utensil is not hygiene with risk code E5 and E9. The risk was chosen because the resulting impact can affect a product's halal status and are not included in the low-risk category. The researchers compiled some proposed mitigations through the risk that is identified (Table 4).

Table 4: Risk mitigation of halal product

\begin{tabular}{|c|c|c|}
\hline Code & Risk Event & Risk Response/Mitigation \\
\hline E1 & $\begin{array}{l}\text { The slaughtering process is not in line with } \\
\text { Syariah }\end{array}$ & $\begin{array}{l}\text { a. Choose supplier that already have halal certificate and } \\
\text { trusted. }\end{array}$ \\
\hline E3 & $\begin{array}{l}\text { The raw material exceeds the expiration } \\
\text { date }\end{array}$ & $\begin{array}{l}\text { b. Double checking while still at the supplier which have } \\
\text { not been delivered and also after being delivered. }\end{array}$ \\
\hline E5 & $\begin{array}{l}\text { Raw material is contaminated by non-halal } \\
\text { substance }\end{array}$ & c. Make two chamber or separate inventories \\
\hline E9 & The cooking utensil is not hygiene & $\begin{array}{l}\text { d. Make separation equipment between halal and non } \\
\text { halal }\end{array}$ \\
\hline E1 & $\begin{array}{l}\text { The slaughtering process is not in line with } \\
\text { Syariah }\end{array}$ & e. make SOP related hygiene and guideline to employee \\
\hline
\end{tabular}

\section{CONCLUSSION}

Halal risk management should be considered in halal requirement. To fulfill those requirements this paper shows five halal critical points in fast food restaurant supply chain from the first procurement to the end consumer. The researcher was identified 11 risk event that occur with different probability and severity value. This paper using risk map method to measure the critical risk with calculating Risk Priority Index (RPI). The risk map result show there 4 significant risk that categorized medium and high risk such as the slaughtering process is not in line with Syariah, the raw material exceeds the expiration date by code E3. In addition, in the inventory and production process also has significant risk that had been identified such as raw material is contaminated by non-halal substance and cooking utensil is not hygiene with risk code E5 and E9. The risk was chosen because the resulting impact can affect a product's halal status and are not included in the low-risk category. The researchers compiled some proposed mitigations through the risk event before such as choose supplier that already have halal certificate and trusted, double checking while still at the supplier which have not been delivered and also after being delivered, make two chamber or separate inventories, make separation equipment between halal and non halal, and make SOP related hygiene and guideline to employee.

\section{REFERENCES}

[1] DE ANDRADE ML, RODRIGUES RR, ANTONGIOVANNI N, DA CUNHA DT. Knowledge and risk perceptions of foodborne disease by consumers and food handlers at restaurants with different food safety profiles. Food Res Int 2019; 121:845-53. https://doi.org/10.1016/j.foodres.2019.01.006.

[2] KAZI RNA, EL-KASHIF MML, AHSAN SM. Prevalence of salt rich fast food consumption: A focus on physical activity and incidence of hypertension among female students of Saudi Arabia. Saudi J Biol Sci 2020:6-10. https://doi.org/10.1016/j.sjbs.2020.06.004.

[3] CHO M, BONN MA, GIUNIPERO L, DIVERS J. Restaurant purchasing skills and the impacts upon strategic purchasing and performance: The roles of supplier integration. Int J Hosp Manag 2019; 78:293303. https://doi.org/10.1016/j.ijhm.2018.09.012.

[4] AKHTAR N, SUN J, AHMAD W, AKHTAR MN. The effect of non-verbal messages on Muslim tourists' interaction adaptation: A case study of Halal restaurants in China. J Destin Mark Manag 2019; 11:10-22. https://doi.org/10.1016/j.jdmm.2018.10.001.

[5] OLYA HGT, AL-ANSI A. Risk assessment of halal products and services: Implication for tourism industry. Tour Manag 2018; 65:279-91. https://doi.org/10.1016/j.tourman.2017.10.015.

[6] AHMAD AN, ABDUL RAHMAN R, OTHMAN M, UNGKU ZAINAL ABIDIN UF. Critical success factors affecting the implementation of halal food management systems: Perspective of halal executives, consultants and auditors. Food Control 2017; 74:70-8. https://doi.org/10.1016/j.foodcont.2016.11.031. 
[7] HAN H, AL-ANSI A, OLYA HGT, KIM W. Exploring halal-friendly destination attributes in South Korea: Perceptions and behaviors of Muslim travelers toward a non-Muslim destination. Tour Manag 2019;71:151-64. https://doi.org/10.1016/j.tourman.2018.10.010.

[8] AL-ANSI A, OLYA HGT, HAN H. Effect of general risk on trust, satisfaction, and recommendation intention for halal food. Int J Hosp Manag 2019; 83:210-9. https://doi.org/10.1016/j.ijhm.2018.10.017.

[9] MATHEW VN, ABDULLAH AMR BINTI A, ISMAIL SN BINTI M. Acceptance on Halal Food among Non-Muslim Consumers. Procedia - Soc Behav Sci 2014; 121:262-71. https://doi.org/10.1016/j.sbspro.2014.01.1127.

[10] MAHBUBI A, UCHIYAMA T, HATANAKA K. Capturing consumer value and clustering customer preferences in the Indonesian halal beef market. Meat Sci 2019; 156:23-32. https://doi.org/10.1016/j.meatsci.2019.05.012.

[11] BRUWER J, COHEN J. Restaurants and wine by-the-glass consumption: Motivational process model of risk perception, involvement and information-related behaviour. Int J Hosp Manag 2019; 77:270-80. https://doi.org/10.1016/j.ijhm.2018.07.006.

[12] GORECKI S, RIBAULT J, ZACHAREWICZ G, DUCQ Y, PERRY N. Risk management and distributed simulation in Papyrus tool for decision making in industrial context. Comput Ind Eng 2019; 137:106039. https://doi.org/10.1016/j.cie.2019.106039.

[13] SHI X, LIAO Z. Managing supply chain relationships in the hospitality services: An empirical study of hotels and restaurants. Int J Hosp Manag 2013; 35:112-21. https://doi.org/10.1016/j.ijhm.2013.06.001.

[14] XU M, CUI Y, HU M, XU X, ZHANG Z, LIANG S, et al. Supply chain sustainability risk and assessment. J Clean Prod 2019; 225:857-67. https://doi.org/10.1016/j.jclepro.2019.03.307.

[15] OLIVEIRA FN DE, LEIRAS A, CERYNO P. Environmental risk management in supply chains: A taxonomy, a framework and future research avenues. J Clean Prod 2019; 232:1257-71. https://doi.org/10.1016/j.jclepro.2019.06.032.

[16] JUNG SY, REPETTI T, CHATFIELD HK (GRACE), DALBOR M, CHATFIELD R. Internationalization and accounting-based risk in the restaurant industry. J Hosp Tour Manag 2019; 41:148-55. https://doi.org/10.1016/j.jhtm.2019.11.001.

[17] CHAOUCH S, MEJRI A, GHANNOUCHI SA. A framework for risk management in Scrum development process. Procedia Comput Sci 2019; 164:187-92. https://doi.org/10.1016/j.procs.2019.12.171.

[18] HUSSEINI DE ARAÚJO S. Assembling halal meat and poultry production in Brazil: Agents, practices, power and sites. Geoforum 2019; 100:220-8. https://doi.org/10.1016/j.geoforum.2019.01.014.

[19] SHAHDAN IA, REGENSTEIN JM, SHAHABUDDIN ASM, RAHMAN MT. Developing control points for halal slaughtering of poultry. Poult Sci 2016; 95:1680-92. https://doi.org/10.3382/ps/pew092.

[20] MARZUKI SZS, HALL CM, BALLANTINE PW. Measurement of Restaurant Manager Expectations toward Halal Certification Using Factor and Cluster Analysis. Procedia - Soc Behav Sci 2014; 121:291303. https://doi.org/10.1016/j.sbspro.2014.01.1130.

[21] HENDERSON JC. Halal food, certification and halal tourism: Insights from Malaysia and Singapore. Tour Manag Perspect 2016; 19:160-4. https://doi.org/10.1016/j.tmp.2015.12.006.

[22] HIJRAH M, KADIR A, ZURAIDAH R, MOHD R, SARAH S. Halal Supply Chain Management Streamlined Practices : Issues and Challenges Halal Supply Chain Management Streamlined Practices : Issues and Challenges 2016. https://doi.org/10.1088/1757-899X/160/1/012070.

[23] WAHYUNI D, NASUTION AH, BUDIMAN I, ARFIDHILA N. Halal Risk Analysis at Indonesia Slaughterhouses Using the Supply Chain Operations Reference (SCOR) and House of Risk (HOR) Methods. J Phys Conf Ser 2020; 1542. https://doi.org/10.1088/1742-6596/1542/1/012001.

[24] PONDAAG J, KAWET L, TALUMEWO P. Analisis Rantai Pasok Ketersediaan Bahan Baku Di Industri Jasa Makanan Cepat Saji Pada Kfc Multimart Ranotana. J Ris Ekon Manajemen, Bisnis Dan Akunt 2014; 2:1584-91. https://doi.org/10.35794/emba.v2i3.5918 